DOI: $10.14807 /$ ijmp.v10i4.968

\title{
ORDER OF EMERGENCY ORDERS IN A COMPANY OF DISTRIBUTION OF ELECTRICAL ENERGY
}

\author{
Gustavo Stamm \\ Universidade Federal de Santa Maria (UFSM), Brazil \\ E-mail: gustavo.stamm@terra.com.br
}

Andre Missaggia

Universidade Federal de Santa Maria (UFSM), Brazil

E-mail: andremissaggia@hotmail.com

Bruno Miranda Santos Universidade Federal dos Rio Grande do Sul (UFRGS), Brazil

E-mail: brmiranda10@gmail.com

Franco da Silveira Universidade Federal dos Rio Grande do Sul (UFRGS), Brazil E-mail: franco.da.silveira@hotmail.com

Paulo Cesar Chagas Rodrigues Instituto Federal de Educação, Ciência e Tecnologia de São

Paulo (IFSP), Brazil

E-mail: paulo.rodrigues@ifsp.edu.br

Filipe Molinar Universidade Regional Integrada do Alto Uruguai e Missões (URI),Brazil E-mail: fmacmec@gmail.com

Submission: 01/17/2019 Accept: 02/10/2019

\section{ABSTRACT}

The emergence of emergency orders, in the course of services already underway, in an electricity distribution concessionaire is inevitable, characterizing a dynamic scenario. Minimizing the delays resulting from these emergencies is a challenge for companies that provide this type of service. In this way, such companies need strategies to meet the needs of customers while meeting regulatory requirements. Aiming at this routing problem, the following work aims to identify evaluation criteria in the dispatch of these emergency orders and the impacts that these criteria will result in the execution times of these work orders in an electricity distribution company. 
DOI: 10.14807/ijmp.v10i4.968

As findings of this research, we verify that the demand exceeds the capacity of the teams and that the orders end up being passed on to the next day. Through the criteria, it was possible to prioritize commercial and emergency orders and analyze the impact generated.

Keywords: Emergency Orders; Dynamic Vehicle Routing; Distribution Concessionaires; Decision Criteria

\section{INTRODUCTION}

Service companies that involve any type of vehicle movement, the routing problem appears in a very significant way, in which if it does not have good planning for the routes, it ends up having high costs and wasted time (ULMER et al., 2018). In the electric distribution concessionaires, it is not different, where work teams are destined to perform services programmed a priori, through a static routing, in which they are organized in a row of priorities.

However, in the course of these scheduled services, emergencies are common, which characterizes dynamic routing (HEMERT; LA POUTRÉ, 2004), usually caused by climatic events that cause the electric power to fall and, as a continuous service, must be healed as soon as possible. Thus, the work teams end up performing both corrective and predictive maintenance tasks, as well as commercial services, having a multitasking character. Thus, it is intended to respond through this research as the orders of these emergency services orders are made, considering this scenario of multiobjective dispatch.

In the last three decades, the problem of vehicle routing has been bringing interest to researchers, where most of the efforts are directed towards static and deterministic problems, where information is known for route planning (LARSEN et al., 2002; ULMER et al., 2018). Routing, or travel plan, is a problem encountered in directing vehicles through a network of routes and can be done taking into account the minimum distance, the minimum time or the combination of them (BALLOU, 2008; ZANG et al., 2018). However, the dispatch, unlike routing, considers that load volumes and stops are already known before programming (BALLOU, 2011).

In practice, this does not happen as expected, as in the case of electricity distribution concessionaires, where the occurrence of emergency services ends up 
generating emergency dispatches after determining the daily schedule. For Raduan (2009), all dispatches were once done after scripting, but the advancement of computer and communication technologies made access more reliable with regard to location and instantaneous communication between suppliers, customers and the service provider. Thus, even after the vehicle leaves the base, the plant can identify its location and send service requests, allowing an advance service and advances in levels of improvement for the customer. Through this, dynamic and partially dynamic routing work together with static routing, which has been a more frequent practice.

The proposed theme for the development of the work are the criteria for evaluation of emergency services in electric power concessionaires. For this, it is necessary to evaluate the orders of emergency orders considering the dynamic scenario of the occurrences. Therefore, this article aims to define and measure the impact of service criteria in the definition of times of emergency services.

\section{BACKGROUND}

In the concessionaires of electricity distribution, one of the activities considered to be complex is the attendance to requests for commercial and emergency services (VOLPI et al., 2008; ZHEZHELENKO, 2018). Commercial services are characterized as the connection of a new customer, from cuts to retirement, to the exchange of a meter, among others. Emergency emergencies, according to ANEEL (2002), are characterized as an "event in the electricity network that damages the safety and/or quality of the service provided to the consumer, with consequent displacement of emergency response teams".

These events are associated with the climatic conditions, due to heavy rains and gusty winds, with a strong influence of the high temperature, in which it contributes to the emergence of problems of bad contact in the connections of the branches of the customers and disarming or the burning of transformers by increasing consumption of energy from refrigeration products (ANDRADE et al., 2014).

These services are performed by work teams according to the plans and decisions made by the company's operations center. Commercial services are received in one day and dispatched the next day, as well as emergency services, occur simultaneously with commercial services during the day and must be remedied as soon as possible. In view of this scenario, the reality one has in companies is 
DOI: $10.14807 /$ ijmp.v10i4.968

multitasking teams with a demand for work that is greater than the capacity to perform them.

Although it seems a simple problem, in which one thinks first of putting more work teams to solve the services, one must take into account the costs involved in this decision, because this type of alternative is in fact impracticable. As it is not possible to increase the number of teams, it should be managed in the best possible way, considering innumerable criteria in planning and decision making, in order to serve both services with the least possible impact. Observing the problem in general, where there are many teams, in order to meet the demand of different places, where they come from different places, we can characterize this movement as a typical routing problem.

\subsection{Routing Problem}

The Vehicle Routing Problem (PRV) covers several types of problems that vary according to what you want to achieve. According to Larsen (2009), the PRV is a generalization of the Vendor-Vendor Problem (PCV), in which a vendor visits a sequence of cities (once only for each one) and at the end returns to the city of which left. The objective of this problem is to minimize the total distance traveled by the seller (ELGESEM et al., 2018).

The PRV consists of determining $\mathrm{m}$ routes of vehicles, where the route is a tour that starts in the warehouse, visits a subset of customers in a certain order and, finally, returns to the warehouse (LARSEN, 2009; ULMER et al., 2018 ). All customers need to be visited, exceptionally, once and the total customer demand for a route, should not exceed the capacity of the vehicle. According to Mauri (2006), the problem of routing and scheduling of vehicles is constituted in the development of economic routes to meet customers' transportation requirements, taking into account a series of operational and qualitative restrictions.

Thus, the PRV, as can be observed in Figure 1, aims to develop a group of routes in order to serve all customers, traveling as little as possible and minimizing overall distribution costs (HEMERT, LA POUTRÉ, 2004). However, a series of restrictions makes this model difficult, for example, the total time the route should be made. 


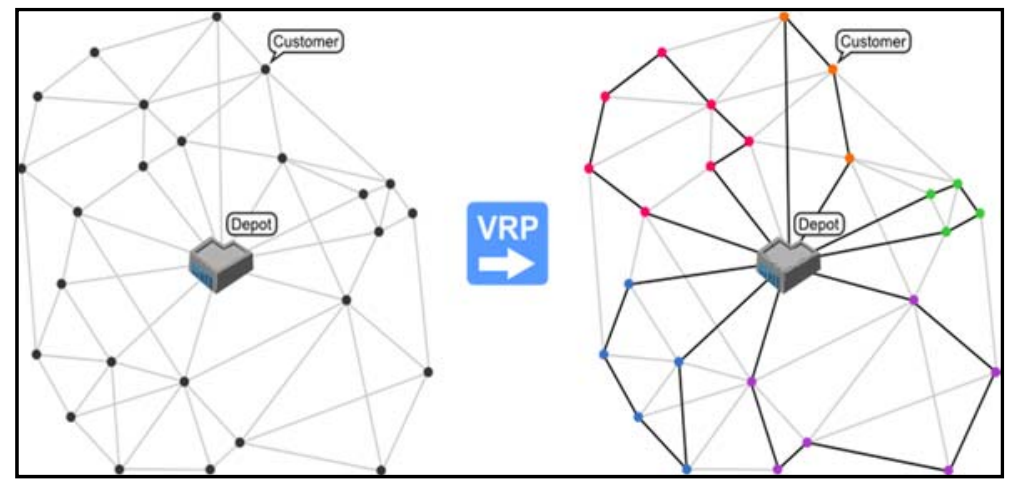

Figure 1: Vehicle Routing Problem

Thus, for Eksioglu (2009), the PRV consists of finding a set $k$ of simple circuits, each corresponding to a vehicle path with a minimum cost, which is defined as the sum of the costs of arcs of the circuits and which follow the following rules: the sum of the demands of the vertices visited by a circuit can not exceed the capacity of the vehicle; each circuit visits the vertex 0 , that is, the deposit (starting point); each vertex $\mathrm{j}$ (client) is exactly visited by a circuit. For the case in question, only two types of routing will be addressed: static and dynamic, but more emphasis is given to the dynamic one since this is what will be used in the case study.

\subsubsection{Static and Dynamic Routing}

Static routing is characterized when information about customers and their demands are all known in advance, a priori, before the vehicles leave, where other variables are often fixed, such as time to service and cost (MATTIA, 2018). In this way, the scheduling of routing becomes easier and simpler, since the variables do not change in the optimization model (RADUAN, 2009). On the other hand, dynamic routing is characterized by the knowledge of the customers and their demands progressively during the vehicles' journey, that is, after their departure, a posteriori (HEMERT; LA POUTRÉ, 2004).

\subsection{Criteria for Decision Making}

In electricity distribution companies, the two types of routing mentioned above can be identified. Teams before leaving the plant have numerous services already established and must be carried out according to an order of priority. As these services were generated before the teams leave the plant, it is characterized as a static routing problem. In this way, it can be said that it is more trivial to determine the routes for the fulfillment of these service orders. However, during the execution of these pre- 
established orders, there are emergencies of emergency orders, which are characterized as nonconformities in the operation of the network, such as the fall of a pole during a weather event, or the burning of a transformer.

The determination of the routes for the fulfillment of these emergency orders will depend on the decision making of the operations center. The choice must be made on the basis of criteria that will consequently bring impacts. These impacts should be defined and measured by minimizing service time, distance traveled and costs. In the bibliography, several authors cite different ways of solving this type of problem with different criteria.

The study by Torres et al. (2004) has the purpose of minimizing the service time in defects occurring in an electrical network, where this time is formed by the displacement time and the repair time. Prata et al. (2008) carried out a study to evaluate the performance of an electric energy distribution concessionaire in order to meet emergency orders, verifying the time required to comply with these orders, taking into account the arrival, detection and standardization processes of occurrences. In the study of Nahuis and Flores (2013), a methodology was developed for automation in the dispatches of the vehicles for the attendance of services in the electricity distribution networks. Ulmer et al. (2018) developed an anticipatory dynamic policy based on approximate dynamic programming to estimate the potential of problem states in relation to future services.

The number of solutions and methods used to deal with the problem of routing and order fulfillment that have a dynamic character is visible. The criteria raised vary according to the company and the type of service it provides. It is clear that this decision will bring some kind of impact to some sector or service of the company because it is difficult to meet all the requirements and, at the same time, not suffer any kind of negative consequences since it is a dynamic scenario and requires a rapid and effective response.

The companies seek to improve their attendance to occurrences because they are motivated due to some factors. One of the main ones is the compliance with regulatory requirements, which is made by ANEEL and which establishes indicators for the monitoring and control of the performance of the distributors in relation to the quality of services and energy supplied. If the minimum requirements required by 
ANEEL are not met, the company will be subject to a fine and/or it will reimburse customers for improper supply. Six indicators are related to the continuity of supply, according to ANEEL (2015), in which they measure the frequency and duration of interruptions in consumers:

a) DEC - equivalent duration of interruption per consumer unit;

b) FEC - equivalent frequency of interruption per consumer unit;

c) DIC - Duration of individual interruption per consumer unit;

d) FIC - Frequency of individual interruption per consumer unit;

e) DMIC - Maximum continuous interruption duration per consumer unit or connection point; and

f) DICRI - Duration of individual interruption occurred on a critical day by consumer unit or connection point.

The indicators are directly connected with the emergency occurrences in the concessionaires, thus requiring as few problems as possible that are connected with the interruption of the supplied energy, but, if it occurs, that the service time to remedy the defect is the smallest possible. Thus, for the cases of dispatch, the indicators that should be considered are the DEC, the DIC, the DMIC and the DICRI, since they are linked with the duration of the interruption, precisely what should be minimized by the concessionaire in emergency occurrences.

Frequency, as is the case with FEC and FIC indicators, is not relevant for dispatch cases only. According to Article 6 of ANEEL Resolution No. 520, which is related to emergency occurrences, the concessionaires should, as of 2003, calculate all their consumer units of the following indicators:

I. Average preparation time (TMP), which is given by the following formula:

$$
T M P=\frac{\sum_{i=1}^{n} T P(t)}{n}
$$

II. Average travel time (TMD), which is given by the following formula:

$$
T M D=\frac{\sum_{i=1}^{n} T D(t)}{n}
$$

III. Average execution time (TME), which is given by the following formula: 
DOI: $10.14807 /$ ijmp.v10i4.968

$$
T M E=\frac{\sum_{i=1}^{n} T E(t)}{n}
$$

IV. Average time of attendance to emergency occurrences (TMAE), which is given by the following formula:

$$
T M A E=T M P+T M D+T M E
$$

V. Percentage of number of emergency occurrences with interruption of energy (PNIE), which is given by the following formula:

$$
P N I E=\frac{N I E}{n} \times 100
$$

where,

TP, preparation time of the emergency care team for each emergency;

$\mathrm{n}$, number of emergency occurrences verified in the set of consumer units, in the calculation period considered;

TD, time of displacement of the emergency response team for each emergency;

TE, time of execution of the service until its reestablishment by the emergency service team;

NIE, number of emergency occurrences with interruptions of electric energy.

With these indicators, it is possible to verify that the time of attendance of an emergency service is not only the time required to perform the repair at the place of occurrence but the sum of three-time indicators that make up this final time. For this reason, the routing study is very important for the fulfillment of these orders, because with its decrease and optimization, the total service time will be reduced and, consequently, these indicators will be more positive for the company. On the ANEEL website, it is possible to verify these values according to the concessionaire and the desired year.

\section{METHODOLOGY}

\subsection{Scenario}

This work will be applied to an electric energy distribution company in Rio Grande do Sul. According to data provided, the company serves around one million two hundred and ten thousand clients in a concession area of almost $100,000 \mathrm{~m}^{2}$. The 
work focused on the dispatch of orders for emergency services, which are those that have a dynamic character, without prediction, and that end up affecting the commercial services that are programmed a priori, since they are emergencies, end up being prioritized, generating an impact on the orders commercial activities.

\subsection{Search Method}

The methodology used is applied in nature, with explanatory and descriptive objectives and has a qualitative and quantitative approach. The research method that will be employed in the work is case study. According to (MIGUEL, 2012), this is one of the most used approaches in the country in production engineering and operations management. For Yin (2001), the case study is an empirical study that investigates a current phenomenon in a real situation, usually considering that the boundary between the phenomenon and the situation where it is inserted is not very well defined.

\subsection{Stages of Research}

The work was divided into five parts. In the first stage, we sought to make a general study of the literature, looking for articles, books and works that approached this question and gave a broad idea of the subject and the proposed problem, in order to make its understanding easier and direct, since the has a wide application. After identifying that this type of problem is a typical vehicle routing problem, we aimed to study this topic in specific, through bibliographic research, focusing on two types in particular: static routing and dynamic routing, since these two are found in the concessionaire and their understanding and differences are vital for the development of the work.

Understanding the two types of routing, the next two steps are to raise the criteria that are related to the emergency orders and to seek approaches that contemplate these criteria. For this, we searched for articles and articles applied in cases that have a dynamic scenario and that bring these criteria and how they are treated for the decision making in the dispatch of work orders. Finally, a case study was carried out in an electricity distribution concessionaire to verify the impact of emergency orders on commercial orders, taking into account these criteria.

Initially, the data was taken from a database, in which all service orders with dates, orders, runtime, among others, are stored and converted to Excel. After that, five days of a random month were selected. Through the ANEEL website, it is possible 
to consult data that is sent monthly from the concessionaire to ANEEL, in which one of them is the average time of displacement. Thus, it was possible to determine an exact average value of the displacement time of the teams for the orders. Subsequently, the total execution time of the commercial orders for the five days, without considering the total time of displacement, was calculated. Afterward, the time of displacement was inserted in the execution time and the impact generated by the displacement time was verified, that is, the percentage that is spent in the displacement, considering the total time of execution and displacement.

With the total time of orders, considering the execution time and displacement, the capacity of the concessionaire was calculated, considering for this the 12 teams that work in the field and at 8 hours worked daily. Thus, it was possible to verify, for commercial orders, if the capacity that the company works today meets the requested demand.

The same logic was adopted for the emergency orders, in which the total execution time for the five days was verified after the displacement times and the analysis of their impacts were added and the comparison of the demand with the capacity of the teams. The daily capacity calculation was made and compared to the daily demands to verify that the teams met the commercial and emergency orders on specific days. To finalize the study, the criteria for the dispatch of emergency orders were determined and the impacts generated were analyzed. Figure 2 shows the steps taken to develop this research.

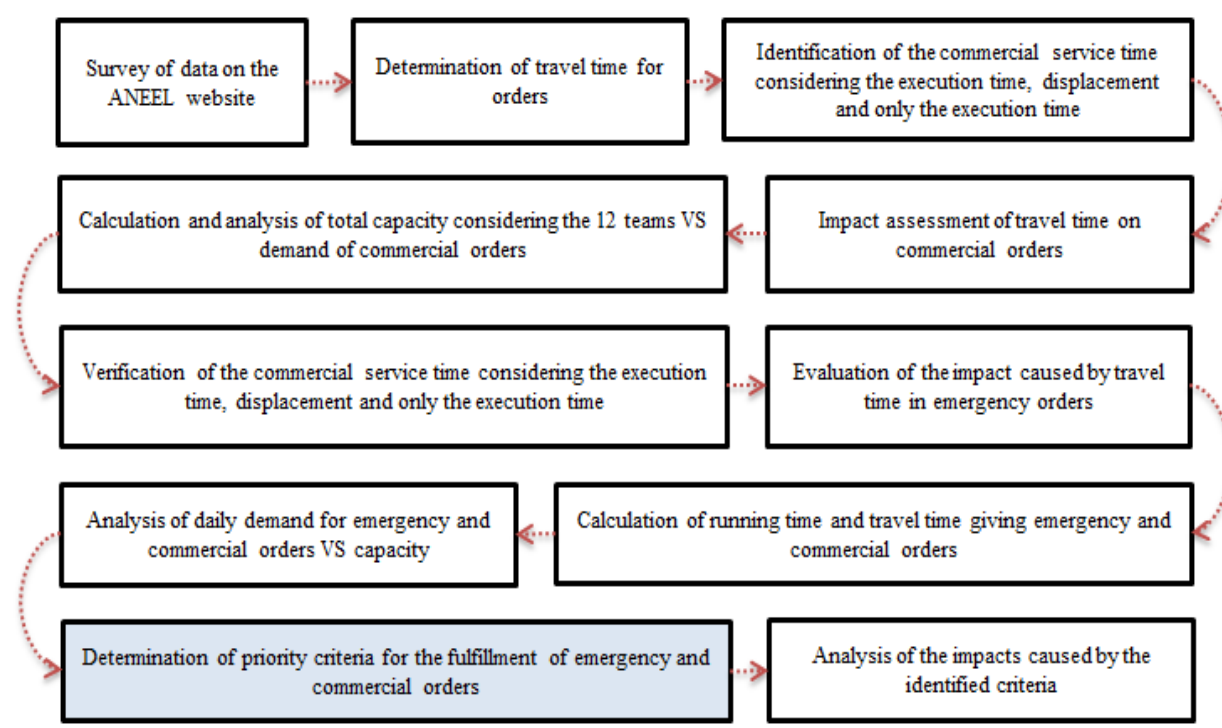

Figure 2: Steps for the development of results 
DOI: 10.14807/ijmp.v10i4.968

\section{RESULTS AND DISCUSSION}

The case study to verify the impacts of emergency orders on commercial orders was made considering data obtained through the head of operations of an electric power distribution concessionaire in the Rio Grande do Sul. These data are all recorded in a database and were exported to Excel to facilitate analysis and manipulation. In Table 1 and Table 2, you can see how elements are organized in Excel for commercial and emergency order data, respectively.

Table 1: Organization of data for commercial occurrences

\begin{tabular}{|c|c|c|c|c|c|c|}
\hline OS & Type_OS & Date_Generation & Date_Deadline & Weather Padrao & Group & Regulated \\
\hline 20302584 & TO562 & $14 / 04 / 201313: 34$ & $17 / 04 / 201323: 59$ & 80 & C & S \\
\hline 20302586 & TO547 & $14 / 04 / 201314: 03$ & $24 / 04 / 201323: 59$ & 90 & C & N \\
\hline 20289017 & TO562 & $14 / 04 / 201321: 19$ & $17 / 04 / 201323: 59$ & 80 & C & S \\
\hline 65145843 & TO508 & $15 / 04 / 201300: 00$ & $15 / 05 / 201323: 59$ & 30 & A & N \\
\hline 70140690 & TO508 & $15 / 04 / 201300: 00$ & $15 / 05 / 201323: 59$ & 30 & A & N \\
\hline 75140247 & TO508 & $15 / 04 / 201300: 00$ & $15 / 05 / 201323: 59$ & 30 & A & N \\
\hline
\end{tabular}

It can be seen in Table 1 that the orders can be divided into two large groups, those regulated and those not regulated by ANEEL. This field is very important for ordering orders, as it is responsible for indicating the priority level of the service. If it is regulated by ANEEL, the order must be made as soon as possible, otherwise, there is greater flexibility. This can be proven when checking the Date_Generation and Date_Deadline fields because in the case of regulated orders, the deadline for completing the service is much lower than the unregulated orders. Another important point is that the order locations are all made via geographical coordinates, through latitudes and longitudes, and not by addressing.

Two other fields that have correlation are Type_OS and Default Time. The operating time of each service is standard, so, according to the type of service order, the operating time will already be defined, for example, by analyzing Figure 6 , the TO508 service order is observed. The default time for this operation is 30 minutes since the T0562 is 80 minutes. The definition of this standard time assists in the scheduling of work orders, since it is possible, from this definition of time, to give an estimate of how many orders it may be possible to attend during the day. The OS field is only for displaying the generated service order number and the Group field is for separating orders that are of the technical $(\mathrm{T})$ or customer $(\mathrm{C})$ type. The orders that are referring to customers have a shorter term to be met. 
Table 2: Organization of data for emergencies

\begin{tabular}{|c|c|c|c|}
\hline OT & Cli_Inter & Time_Foreseen & Start \\
\hline 4287450 & 1 & 1 & $18 / 04 / 2013$ 08:47 \\
\hline 4287400 & 141 & 1 & $18 / 04 / 201309: 01$ \\
\hline 4287505 & 526 & 1 & $18 / 04 / 201310: 05$ \\
\hline 4287795 & 1 & 1 & $18 / 04 / 201311: 28$ \\
\hline 4287804 & 1 & 1 & $18 / 04 / 201311: 36$ \\
\hline 4287605 & 45 & 1 & $18 / 04 / 201312: 10$ \\
\hline 4287698 & 1 & 1 & $18 / 04 / 201312: 15$ \\
\hline
\end{tabular}

Five days of occurrences, both commercial and emergency, were analyzed. These days correspond to one week of weekdays, from Monday to Friday, and were randomly selected in a month of the year, disregarding the months of January and February due to the holiday season. As commercial orders are despatched on the day after the day of receipt, the interval from Sunday to Thursday was considered. For the emergency orders, which are dispatched on the same day, it was considered Monday through Friday. In total, 327 commercial orders and 128 emergency orders were analyzed.

Table 2 shows that there are fewer fields than commercial orders. The order localization system continues to be geographic coordinates. One of the most important fields for this type of order is the Cli_Inter, which corresponds to the number of clients that were affected by the generated emergency order. At the time of order, this data will have a very large weight for decision making. In the field Time_Foreseen all emergency orders are estimated with the execution time of one hour of duration. An important point that should be highlighted is that in the emergency orders there is the Start field, which would correspond to the Date_Generation of the commercial orders, but in the emergency services, there is no deadline because these services must be executed as soon as possible. Another relevant issue is that emergency orders are generated in one day and dispatched as early as that day, unlike commercial ones, which are generated in one day and dispatched only the day after. In the case of Figure 3 , the first order was generated on $04 / 14 / 2013$, so it will be despatched only on 04/15/2013, because the operations center processes all orders received on the day and orders, in according to priorities, the best execution sequence, which in fact characterizes static routing.

To begin the practical analysis of the data, it is necessary to take into account that the time of attendance to a certain emergency occurrence is not only composed 
by the time of execution of the service to restore the problem, as regulated by ANEEL in the TMAE indicator. This means that you need to set a time-out so that it can be added to the run-time and thus result in a value closer to the indicator, making the analysis more accurate. For that, the values provided by the concessionaire to ANEEL (2015) were used, in which every month the company carries out a survey of all orders with the travel times and sends them to ANEEL for analysis and registration.

The TMAE is also composed by the processing time of the emergency order. However, the study was not considered, since the focus of the study is to analyze the impact of orders of emergency orders taking into account only the external environment and not the internal environment of the company.

Firstly, the demand for commercial orders was analyzed, in which all service execution times for the five days and the travel times were summed up and the impact of the time spent to the displacement to the places of service was verified. The total execution time was 364 hours and the displacement time was 174 hours, which totaled 538 hours. With this, one has $32 \%$ of the time is spent with displacement. Comparing the total execution and displacement time with the teams' capacity in the five days, which is 480 hours, it can be seen that, for the total of that period, teams will not be able to respond to commercial orders with a surplus of 58 hours.

In Figure 3 it is possible to observe the graph of the demand Vs the capacity of the teams, in which the demand is divided in execution time and time of displacement and also of the demand Vs daily capacity. In this case, analyzing the five separate days and not the total, it can be observed that on the 2nd, 3rd and 4th day the demand exceeds the daily capacity, which is 96 hours. On the first day it is observed that the demand is very low, because the corresponding day of the week is a Monday, which indicates that the orders were received on Sunday and, consequently, has a very low demand compared to the rest of the days. On day 5 , demand almost equals capacity, with only two hours off. 


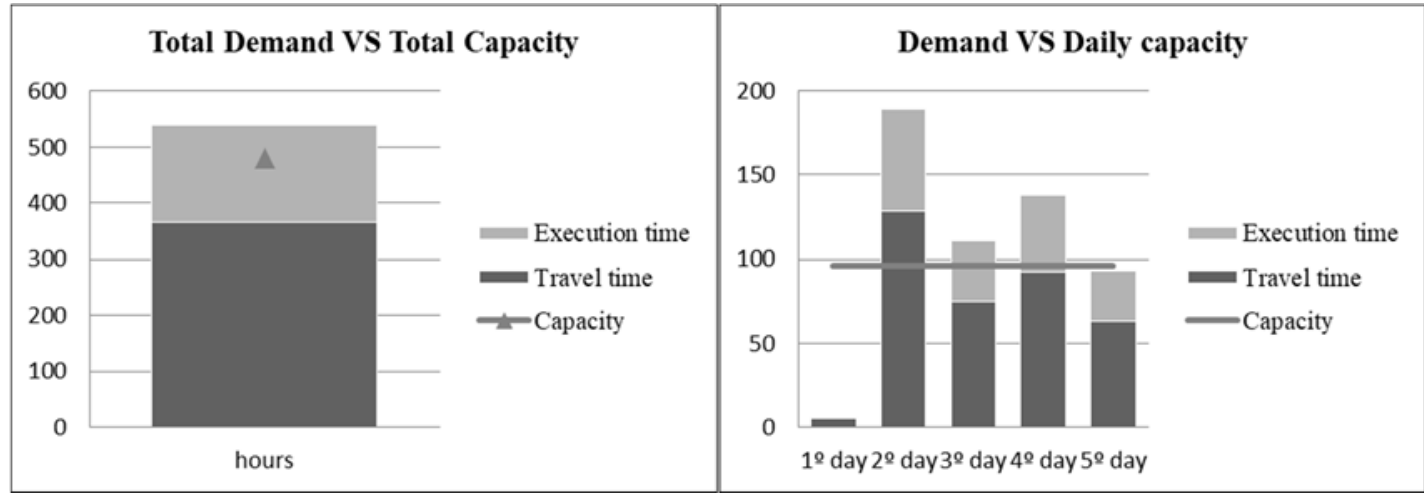

Figure 3: (a) total demand Vs commercial orders and (b) demand Vs capacity daily business orders

By doing the same analysis, using the same principle but now for the emergency orders, it is verified that in Figure 4 the demand is much smaller than the capacity of the teams, showing that the number of emergency orders is smaller than those of the commercial orders. The total execution time for the emergency orders is 128 hours and the total travel time is 68.3 hours, which in total results in 196.3 hours. With this, it can be seen that $35 \%$ of the total time for emergency orders is spent in displacement.

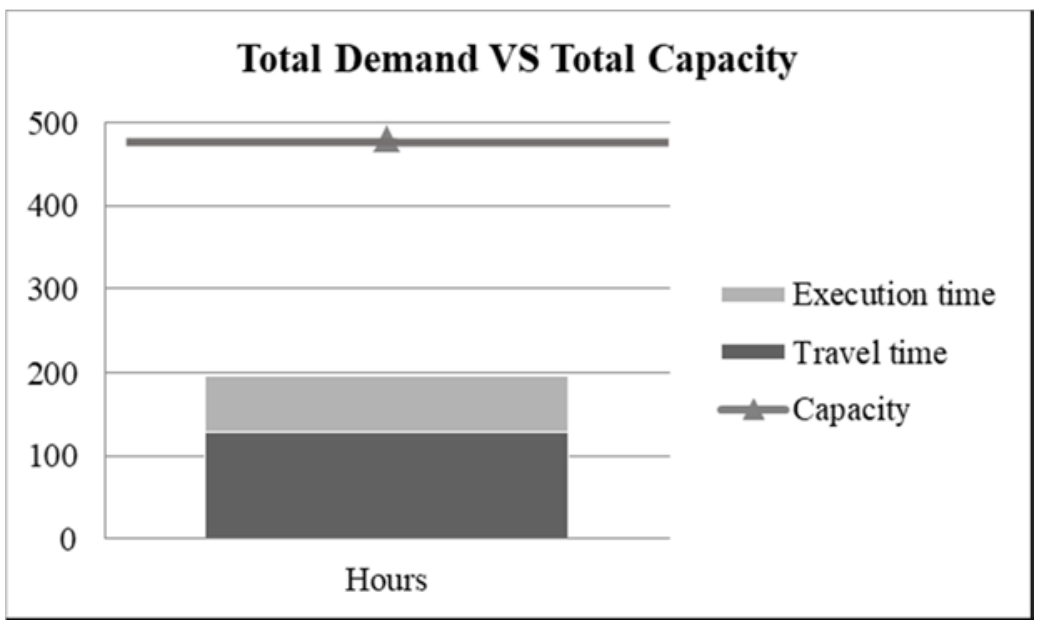

Figure 4: Demand Vs Capacity for commercial orders in the five days

Analyzing now Figure 5, it is verified that in all the five days the demand is well inferior to the capacity of the teams, practically the half. On the 3rd day there was a slight drop. Compared to commercial orders, the difference between the two types of services is notorious considering the daily routine of the work teams, but it must be considered that the emergency orders do not have a standard demand and can thus suffer peaks without any prediction. 


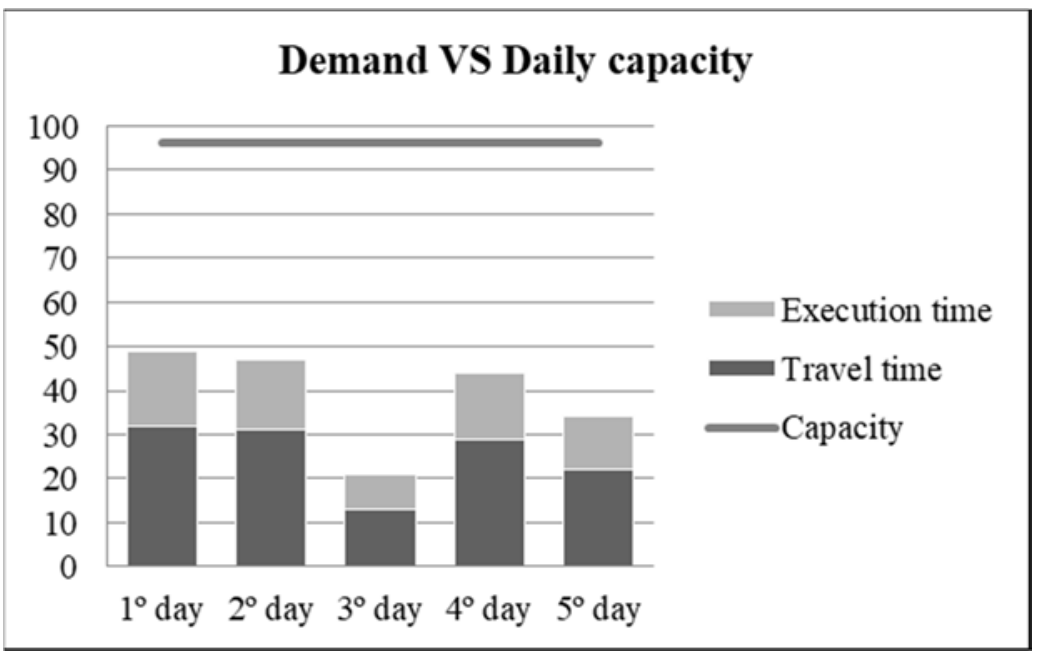

Figure 5: Demand Vs Capacity for emergency orders per day

After analyzing the isolated commercial and emergency orders and verified that the capacity on certain days is exceeded by the demand, it is necessary to verify how the two types of order behave when analyzed together on the days in question. In Figure 6 , it is possible to verify that in four of the five days the orders surpass the capacity of the teams. That's because on Monday the demand is extremely low, if it followed the pattern of other days of the week, it would also exceed the capacity of the teams. Since the capacity is lower than the demand of the daily orders, it is necessary to prioritize the orders in such a way that the impact on these delays is the smallest possible, since it is impracticable to perform all services on the same day.

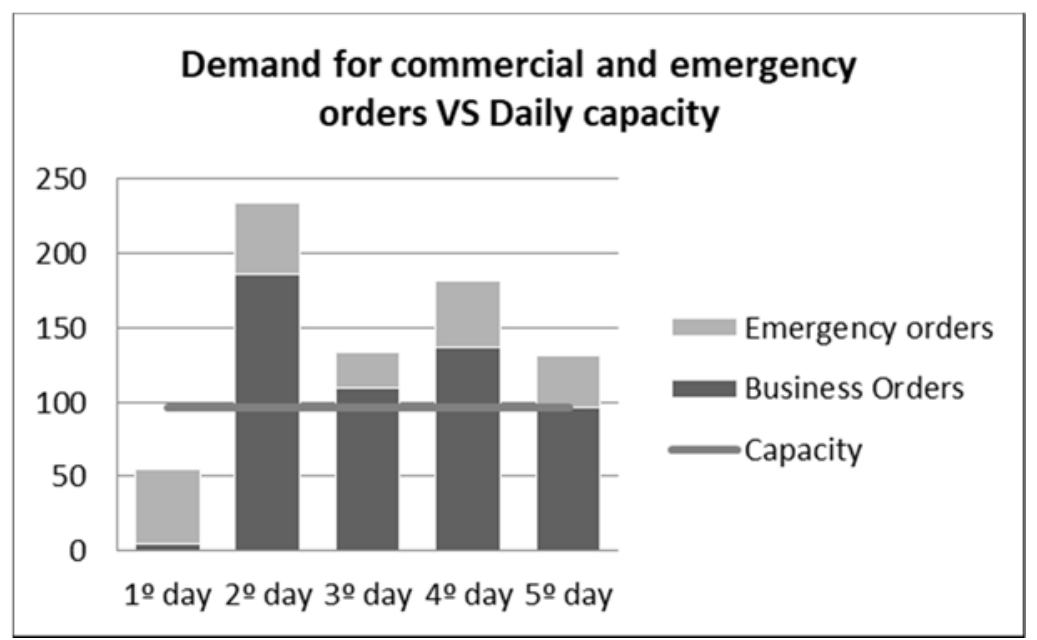

Figure 6: Demand Vs Capacity for commercial and emergency orders per day

Focusing primarily on commercial orders, the prioritization should be made taking into account the criteria that bring a greater impact to the concessionaire. With this, the orders should be prioritized according to the one that has a shorter term in the Date_Foreseen column, since it is precisely the orders that are regulated by 
ANEEL. In this way, the criterion of service of commercial orders is given by the term of attendance of the service. If the term is the same, the prioritization will be made based on the Group column, which refers to whether the order is technical or customer request, in which if requested by the customer must be met first. If there is still a tie between the orders, the criterion should be the FCFS (the first one that arrives is the first one to be attended).

For emergency orders, they should always be prioritized in relation to the commercial ones, because the impact caused by the interruption time of electric power affects more than the delay of the commercial orders. This is because in addition to ANEEL supervise this time with the indicators DEC, DIC, FIC, DMIC and DICRI the concessionaire receives a fine proportional to the interruption time, ie, the longer the time without electricity, the greater the fine for the company. In addition, among the emergency orders, there must be criteria for the sequencing and dispatch of the orders. Using the same logic of the commercial orders, criteria were determined that aim to minimize the impacts generated by the company.

Emergency orders do not have a date or time to arrive, so it is not possible to predict your demand. Therefore, your order must be analyzed before being sent to the teams, so that they are not passed on immediately upon receipt. If this occurs, there may be a risk that an emergency order will be dispatched to a particular team in zone $X$ and then another emergency order with a higher priority will arrive and in the same area of the same emergency previously received. In this way, the team will have to move again to meet the second emergency.

Thus, it was determined that the orders will be dispatched every 10 minutes, because that way you can have a more exact schedule, avoiding this type of problem. Within these 10 minutes, incoming orders will be organized first according to the number of customers affected, because the larger the number of customers, the greater the impact generated by the emergency. After this criterion, the FCFS logic must be considered, since the interruption time should be minimized to the maximum. Finally, the emergency orders should be dispatched to the teams closest to what happened, precisely to reduce the travel time and minimize the time of the interruption.

After determining the criteria, it is necessary to verify what the impacts they bring to the commercial orders since the emergencies will be prioritized. By ordering 
the orders according to the priority, it is possible to visualize, through Figure 7, how unregulated commercial orders will be delayed due to this ordering. Because they have extensive timeframes for service fulfillment, this sequencing method will minimize the impacts, in general, of the utility. Parts of regulated orders will also suffer from this prioritization, but since commercial orders will be despatched according to the shortest delivery time, regulated orders remaining to the end will not suffer delays if left to the next day, or even to the next.

If we quantify the impacts generated by this prioritization, we will have that on the 1st day all the orders will be answered without any delay and that there will still be 90 hours of rest. On day 2, regulated orders exceed 68.63 hours and unregulated orders 71.63 hours. On the 3rd day, the unregulated orders exceeded in 37.1 hours and the regulated ones can be attended all day. On the 4th day, regulated orders exceed capacity in 32.3 hours and unregulated orders in 54.38 hours. Finally, on the 5 th day, only unregulated orders exceed capacity at 31.86 hours.

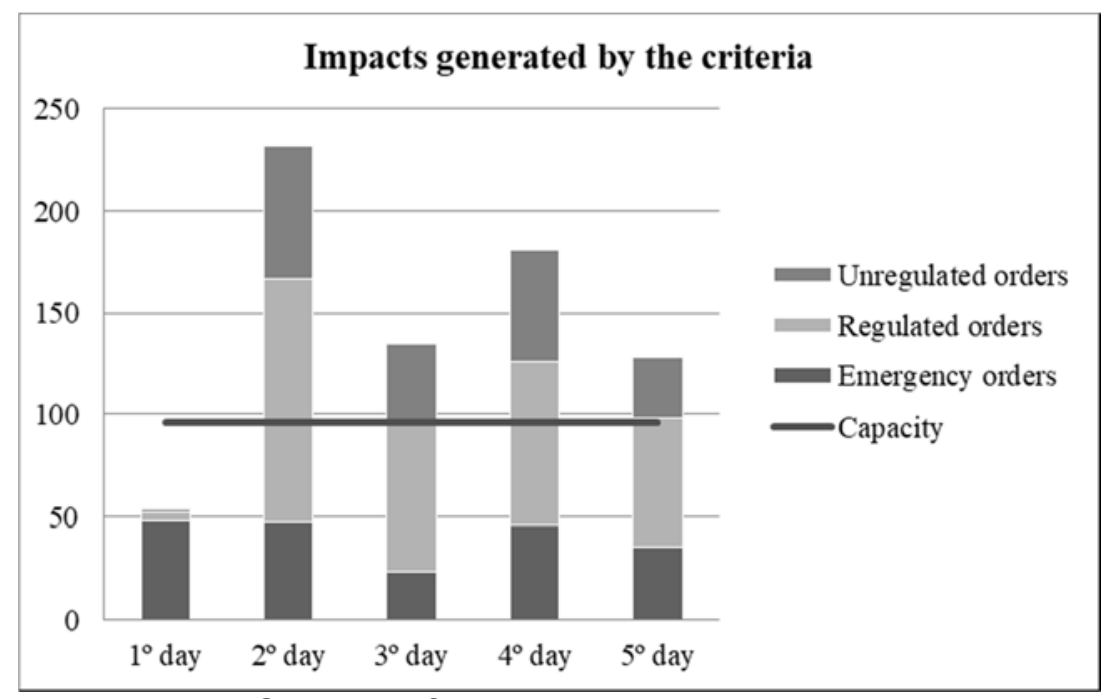

Figure 7: Demand Vs Capacity for commercial and emergency orders per day

Obviously, orders that are not fulfilled on a given day should be repositioned the day after with a higher priority. Thus, Figure 8 was assembled based on this idea of checking at the end of the week how much of regulated and unregulated orders would be pending. Even if unregulated orders have a lower priority than regulated and emergency orders, they can not be left aside, since in the end their amount would be too large and could suffer delays. Thus, it was determined that 10 hours daily will be devoted to unregulated orders, avoiding this accumulation. 


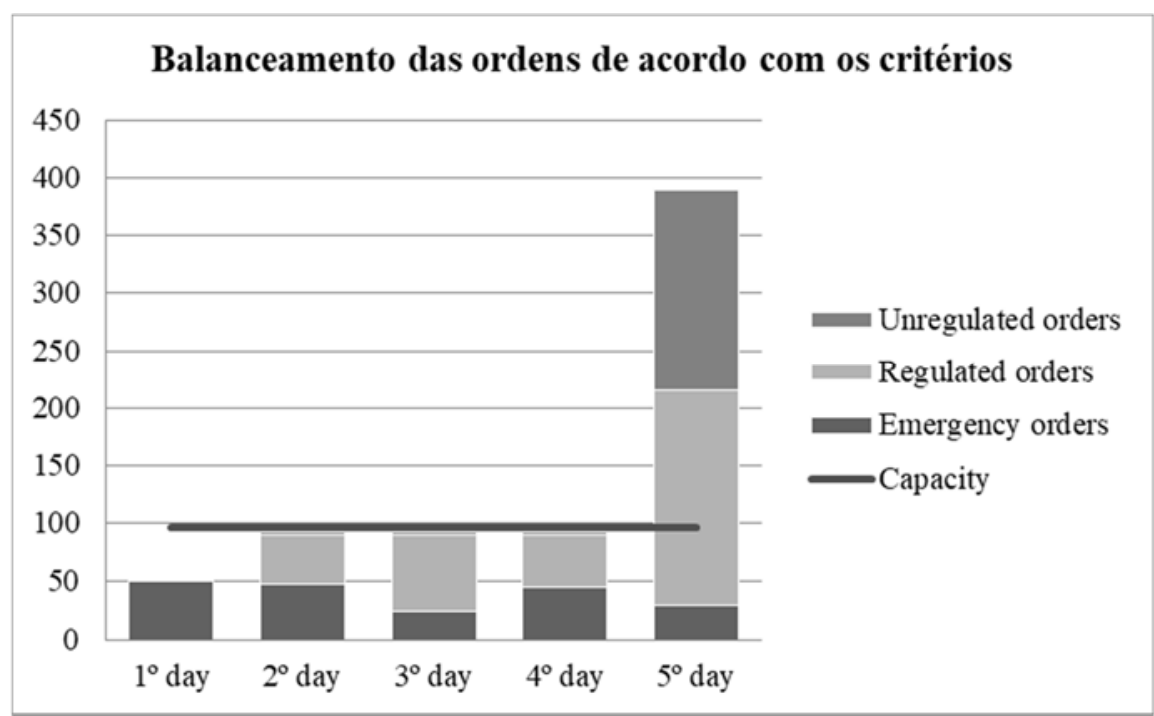

Figure 8: Demand Vs Capacity for commercial and emergency orders per day

For regulted orders, an amount of 124.3 hours was outstanding at the end of the week. For the non-regulated orders, a total of 171.6 hours was recorded. These Figures show the impact generated on regulated and unregulated trade orders. Although the number of emergency orders is much lower than that of commercial orders, the impact they cause for being priorities is very high, so criteria should be stipulated to try to minimize these delays as much as possible.

\section{CONCLUSION}

The determination of criteria for emergency orders in electric power distribution concessionaires is extremely important, since all the companies that operate in this branch have an imbalance between the capacity of the teams and the demand of the commercial and emergency orders, in which these work teams fail to account for all calls within the number of teams and the proposed workload. Because of this excess demand, it is critical to determine these criteria to prioritize what is most important to the company. Obviously, this prioritization, as a consequence, leads to impacts, which must be measured and minimized.

The development of the work to verify the proposed theme is based on the data analysis, with the aid of the computational tool Excel for the manipulation and development of the calculations and graphs, collected from an electric power distribution concessionaire. Basically, the company's current capacity was compared with the demand for commercial and emergency orders. Based on the company's data, it was sought to determine criteria to prioritize orders seeking to reduce the impacts generated in commercial orders. 
Through the calculations and graphs, it was possible to verify that the demand greatly exceeds the capacity of the teams and that the orders end up being passed on to the next day. Through criteria, it was possible to prioritize commercial and emergency orders and analyze the impact generated by this prioritization. With this, it was verified that at the end of the week there will be an accumulation of orders that were passed to the next day. Of the regulated orders, $37 \%$ was accumulated on the last day. Non-regulated, a total of $84 \%$.

A factor that calls attention is the time of displacement of the teams until the occurrence, which consumes $35 \%$ of the time. I believe that an analysis could only be made in the routing area of the vehicles to try to reduce this number and, consequently, increase the number of orders answered in a day of work. Increasing the number of teams and the workload is also an option, but you need to analyze the costs that this will eventually entail. Since on Mondays the demand is very low, you can use that day to put the latest orders up.

\section{REFERENCES}

AES Sul. (2015) Histórico. Rio Grande do Sul. Disponível em: <https://www.aessul.com.br/site/empresa/Perfil.aspx>. Acesso em: 11 jun. 2017.

ANEEL. AGÊNCIA NACIONAL DE ENERGIA ELÉTRICA. (2015) Aplicações tempos médios de atendimento. Rio Grande do Sul. Disponível em: < http://www.aneel.gov.br/aplicacoes/Tempos_medios_de_atendimento/>. Acesso em: 10 nov. 2017.

ANEEL. AGÊNCIA NACIONAL DE ENERGIA ELÉTRICA. (2012) Estabelece os procedimentos de registro $e$ apuração dos indicadores relativos às ocorrências emergenciais. Resolução $N^{0} 520$, de 17 de setembro de 2012. Disponível em: http://www.aneel.gov.br/cedoc/bres2002520.pdf>. Acesso em: 23 out. 2017.

ANDRADE, F. J.; SANTOS, J. C.; MÔNACO, D. R.; FERREIRA, A. A.; CAMARGO, J. (2009) Redução no Tempo Médio de Atendimento a Ocorrências Emergenciais Aplicando o Sinalizador de Faltas. Escola Politécnica da Universidade de São Paulo, Companhia Piratininga de Força e Luz CPFL e Expertise Engenharia Ltda.

BALLOU, R. H. (2011) Logística empresarial: transportes, administração de materiais e distribuição física. São Paulo: Atlas.

BORCHARDT, M.; SELLITTO, M. A.; PEREIRA, G. M. (2008) Serviços de pósvenda para produtos fabricados em base tecnológica. Produção Online. Florianópolis, n. 2.

CARDOSO, F. G.; VIEIRA, J. G. V.; SILVA, J. E. A. R.; FIGUEIREDO, A. M. (2014) Avaliação do nível de serviço logístico de uma empresa distribuidora de autopeças. Produção Online, v. 14, n. 4, p. 1348-1377. 
EKSIOGLU, B.; VURAL, A. V.; REISMAN, A. (2009) The vehicle routing problem: a taxonomia review. Computers e Industrial Engineering, v. 57, n. 4, p. 1472-1486.

ELGESEM, A. S.; SKOGEN, E. S.; WANG, X.; FAGERHOLT, K. (2018) A traveling salesman problem with pickups and deliveries and stochastic travel times: An application from chemical shipping. European Journal of Operational Research.

FORTES, B. J. (2015) Análise e modelagem do atendimento de ordens de serviço emergenciais em concessionárias de energia elétrica. Dissertação (Mestrado em Engenharia de Produção) - Universidade Federal de Santa Maria, Santa Maria.

GOLDBARG, M. C.; LUNA, H. P. L. (2005) Otimização Combinatória e Programação Linear. 2. Ed. Rio de Janeiro: Editora Campus.

HEMERT, J. I.; LA POUTRÉ, J. A. (2004) Dynamic routing problems with fruitful regions: Models and evolutionary computation. International Conference on Parallel Problem Solving from Nature. Springer, Berlin, Heidelberg, p. 692-701.

LARSEN, A. (2000) The dynamic vehicle routing problem. Dissertação (Ph. D. em Filosofia)-Universidade Técnica da Dinamarca, Dinamarca.

LARSEN, A.; MADSEN, O.; SOLOMON, M. (2002) Partially dynamic vehicle routing: models and algorithms. Journal of the Operational Research Society, Boston , p. 637-646.

MATTIA, S.; POSS, M. A. (2018) comparison of different routing schemes for the robust network loading problem: polyhedral results and computation. Computational Optimization and Applications, v. 69, n. 3, p. 753-800.

MIGUEL, P. A. C. (2012) Metodologia de pesquisa em engenharia de produção. 2. ed. Rio de Janeiro: Elsevier Editora Ltda.

ÑAHUIS, F. V. C.; FLORES, M. J. R. (2013) Automação do despacho dinâmico de viaturas para o atendimento das ordens de serviços nas redes de distribuição de energia elétrica. In: SIMPÓSIO BRASILEIRO DE PESQUISA OPERACIONAL, 2013, Natal. Anais eletrônicos... Natal. Disponível em:

<http://www.din.uem.br/sbpo/sbpo2013/pdf/arq0152.pdf> Acesso em: 21 out. 2017.

PEREIRA, D. L. (2010) Heurística e algoritmo exato para o problema de roteamento de veículos com coleta e entrega simultâneas. Dissertação (Mestrado em Ciência da Computação) - Universidade Federal de Minas Gerais, Minas Gerais.

PRATA, B. A. et al. (2008) Análise de desempenho de sistemas de atendimento emergencial em redes de distribuição de energia elétrica: uma aplicação das redes de petri coloridas. XXVIII ENCONTRO NACIONAL DE ENGENHARIA DE PRODUÇÃO, Rio de Janeiro. Anais eletrônicos... Rio de Janeiro, 2008. Disponível em: <http://www.abepro.org.br/biblioteca/enegep2008_tn_sto_074_527_10870.pdf> Acesso em: 20 out. 2017.

RADUAN, A. C. (2009) Roteirização parcialmente dinâmica aplicada a serviços de campo. Dissertação (Mestrado em Engenharia) - Escola Politécnica da Universidade de São Paulo, São Paulo. 
TORRES, G. L.; DA SILVA, L. B.; AOKI, A. R.; MORAES, C. H. V. (2003) Sistema inteligente de locomoção de viaturas para atendimento da rede de distribuição. In: II CONGRESSO DE INOVAÇÃO TECNOLÓGICA EM ENERGIA ELÉTRICA, 2003, Salvador. Anais eletrônicos... Salvador. Disponível em: <http://www.mfap.com.br/pesquisa/arquivos/20090428154801Sistema\%20Inteligente\%20de\%20Locomocao\%20de\%20Viaturas\%20para\%20Aten dimento\%20na\%20Rede\%20de\%20Distribuicao.pdf> Acesso em: 21 out. 2017.

ULMER, M. W.; SOEFFKER, N.; MATTFELD, D. C. (2018) Value function approximation for dynamic multi-period vehicle routing. European Journal of Operational Research, v. 269, n. 3, p. 883-899.

VOLPI, N. M. P. et al. (2008) Logística de atendimento aos usuários de energia elétrica via simulação. XXVIII ENCONTRO NACIONAL DE ENGENHARIA DE PRODUÇÃO, 2008, Rio de Janeiro. Anais eletrônicos... Rio de Janeiro. Disponível em:

<http://www.abepro.org.br/biblioteca/enegep2008_TN_STO_074_527_10895.pdf> Acesso em: 20 out. 2017.

YIN, R. K. (2001) Estudo de caso: planejamento e método. 2. ed. São Paulo: Bookman.

ZHANG, B.; LI, H.; LI, S.; PENG, J. (2018) Sustainable multi-depot emergency facilities location-routing problem with uncertain information. Applied Mathematics and Computation, v. 333, p. 506-520.

ZHEZHELENKO, I. V. (2018) The Main Directions of Improving the Efficiency of Production, Transmission and Distribution of Electrical Energy. Energitika, v. 61, n. 1, p. 28-35. 